\title{
Simulation of Thailand Flood 2011
}

\author{
S. Wongsa
}

\begin{abstract}
In the 2011, severe flooding occurred in Chao Phraya River Basin during monsoon season was the worst flooding in seventy-two years. The accumulated rainfall from January to October 2011 was approximately 35\% higher than the average years. The overall damage from the floods amounted to THB 1.44 trillion, which ranked as the world's fourth costliest natural disaster. The iRIC (International River Interface Cooperative) model has been used to investigate the Thailand Central Region Flood 2011. Some simulation results compared with field measured flood depth and satellite data are presented to demonstrate applicability of the model. Good performances of simulated results were observed in both flow fields and flood propagations.
\end{abstract}

Index Terms-Chao phraya river basin, iRIC, Thailand flood.

\section{INTRODUCTION}

Extreme flooding in Chao Phraya River basin of Thailand began after five key tropical storms and monsoons had passed through in the year of 2011. The accumulated rainfall from January to October 2011 was found to be approximately $35 \%$ higher than the average years. Severe flooding occurred in 2011 was the worst flooding in seventy-two years. A series of floods and dike breaches took place in several areas from upstream to downstream in Chao Phraya River basin, leaving severe impairments to widespread properties damages such as, infrastructure, economy, tourism, industrial sector, and society. It was a consequence of La Niña phenomena effects. Besides, five key tropical storms and monsoon had passed through, following the intense rain, sporadic showers and rainfall continued to raise the risk of further flooding. But, no rainfall of the intensity as that seen in the early floods occurred.

Factors that contributed to flood crisis range from natural to manmade. Heavy rainfall raised the water level in rivers, floodplains and reservoirs, producing overflowing and flooding to adjoining areas and from upstream to downstream areas at the Gulf of Thailand. The heavy rainfall was the exceeding amount of water flow into particularly two major dams of Bhumibol and Sirikit, reaching a maximum water level and overloading storage capacity. To safe dams and relieve pressure on the control structures, it was necessary to release flood water from them by using emergency spillways that was resulted in the uncontrollable release of water

Manuscript received January 10, 2014; revised March 12, 2014. This work was supported in part by the Hydro and Agro Informatics Institute (HAII) and Science and Technology Postgraduate Education and Research Development Office (PERDO).

S. Wongsa is with the Department of Civil Technology Education, Faculty of Industrial Education and Technology, King Mongkut's University of Technology Thonburi, Bangkok, Thailand (e-mail: sanit.won@kmutt.ac.th). flooding downstream areas. High tides and storm surge in the Gulf of Thailand during the months of October and November 2011 also raised the sea water level and hindered the drainage system (e.g. rivers and pumps) from flood damaged areas into the Gulf of Thailand. Lastly, obstacles like highways, railways, irrigation gates, bridge piers/abutments, canal intruder and aquatic plants created a manmade and natural blockage in the drainage system. The floods disaster caused 754 people deaths, 75 main highways were inaccessible, 65 provinces flooded, and 1.53 million households and 4.07 million people affected. According to the World Bank, overall damage from the Thailand 2011 floods disaster was amounted to THB 1.44 trillion (USD 46.5 billion), ranking to be the world's fourth costliest natural disasters [1], [2].

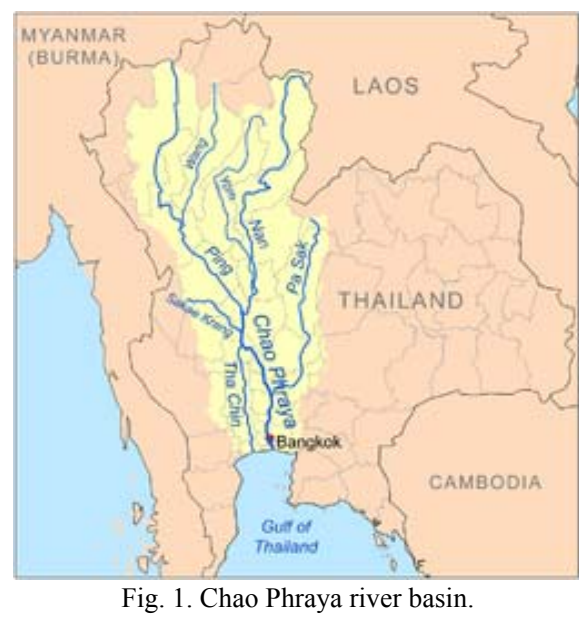

(http://en.wikipedia.org/wiki/chao_phraya_river)

\section{STUDY AREAS}

\section{A. Chao Phraya River Basin}

The Great Chao Phraya can be divided into two parts: the Upper Basin from northern mountainous areas to central of Thailand (Ping, Wang, Yom and Nan rivers), and the Lower Chao Phraya River basin begins at the confluence of the Ping and Nan rivers at Nakhon Sawan province, and then flows to south for $372 \mathrm{~km}$ from the central plains to Bangkok and the Gulf of Thailand (Fig. 1). The Chao Phraya river is the largest river basin in Thailand, the total drainage areas is approximately $157,924 \mathrm{~km}^{2}$, covering about $35 \%$ of the nation's land. In Chainat province, the river splits into the main Chao Phraya river and the Tha Chin river by using the Chao Phraya barrage (dam), then it flows parallel to the main river and exits in the Gulf of Thailand about $35 \mathrm{~km}$ west of Bangkok in Samut Sakhon province. In the low alluvial plain which begins below the Chao Phraya barrage are interconnected by canal (khlong) networks split off from the main river, which serve for irrigation and water 
transportation. In the past, the lowland areas of the Chao Phraya river delta was designated as the freshwater swamp forests (with approximately $400 \mathrm{~km}$ north to south and 180 $\mathrm{km}$ wide), but it has almost entirely been removed as the plain, and then converted to shrimp ponds, other agriculture, urban areas and industrial estates.

TABle I: Chao Phraya River Basin Mean Monthly Climate Data (1981-2010, 30 YEARS)

\begin{tabular}{|l|l|l|}
\hline Items & Monthly ranges & Yearly average \\
\hline Temp. $\left({ }^{\circ} \mathrm{C}\right)$ & $24.6-31.4$ & 28.3 \\
\hline Rel. humidity $(\%)$ & $60.4-82.8$ & 72.7 \\
\hline Cloudy $(1-10)$ & $2.5-8.6$ & 6.0 \\
\hline Wind vel. $(\mathrm{Kt})$ & $0.9-5.0$ & 2.4 \\
\hline Pan evap. $(\mathrm{mm})$ & $115.9-221.4$ & $1,793.2$ \\
\hline
\end{tabular}

\section{B. The Climate and Hydrology}

The climate of the Chao Phraya River basin has a tropical wet and dry or savanna climate, which generates wet and dry seasons of more or less equal length. The monsoon season is usually from May until late September and/or early October. In the wet season, averagely 1 - 2 tropical depressions occur over much of the area from August to October of the year. The seasonal range of mean temperatures in the mountainous and central plain is not large, temperatures normally range from an average annual high of $31.4{ }^{\circ} \mathrm{C}$ to a low of $24.6{ }^{\circ} \mathrm{C}$ (Table I). The rainfall climate of the Chao Phraya River Basin can be determined by the tropical monsoon from year to year. Every area of the areas receives adequate rainfall, but the duration of the rainy season and the amount of rain vary substantially from region to region and with altitude. The average annual rainfall varied between 1,122 to $1,511 \mathrm{~mm}$, depending on monsoon direction and elevation.

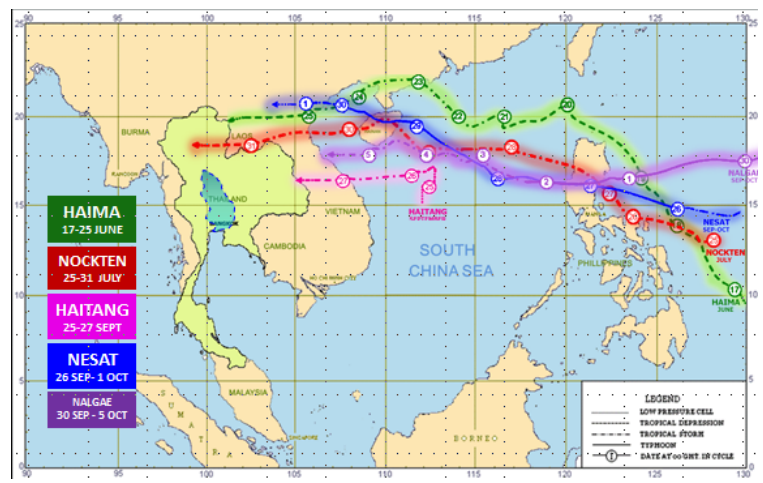

Fig. 2. Tropical storms affected Thailand in 2011. (RID, Thailand).

\section{Details of Thailand Flood 2011}

In this year, flash flood affected some areas in upper Thailand since mid-May. Heavy rainfall occurred in many locations throughout the month in June was caused by the influence of the active southwest monsoon and monsoon trough which lies across the upper Thailand (Fig. 2). The tropical depression "Haima" led to heavy rainfall in several areas, especially in the northern part where flash floods and landslides had been reported in some areas during late June. In late July, downpour rain continued in many areas in addition with tropical depression "Nock-Ten" that was moved into the area of Nan province on July 31 before weakening to the low pressure cell covering the northern part. This brought heavy rain to several areas, resulting in widespread flooding in north and northeast parts. During August to September, many areas such as northern, central and northeastern parts experienced wet condition caused by the active southwest monsoon and the rather active monsoon through. Massive flooding persisted mainly in lower northern and central parts. In October, the late rainy season in normal year, the northeast monsoon prevailed over Thailand since around mid-month. Meanwhile, the monsoon trough moved southward to lie across central Thailand, bringing occasional rainfall. The accumulated precipitation from January to October 2011 was 35\% higher than average annual rainfall. Seasonal rainfall from May to October in 2011 was above normal of $20-60 \%$ for most Meteorological Station in northern part (Fig. 3). The flood peak at station C.2 (Nakhon Sawan province) was $4,686 \mathrm{~m}^{3} / \mathrm{s}$ which is not the largest flood peak, but the total yearly runoff was 52,961 MCM (Million Cubic Meter) compared with average yearly runoff is 23,140 MCM. (Fig. 4). In the beginning of season to end of June, few water was demanded, no need to drain water from two major dams. But, in August to mid-September water level in Sirikit dam was higher than normal retention water level, forcing to open emergency spillway to safe dam from Haima storm and monsoon through.

In the same periods, Bhumibol dam outflow was increased, however it was restricted by flooding in lower Nan river and upper central areas. During mid-September to early November, there was high flow in the beginning and outflow was reduced after mid-October. Since flood water was still higher than normal outflow, therefore, flood water had to be released by emergency spillway for dam safety and relieve pressure on the control structures, from Sirikit and Bhumibol dam, respectively [3].
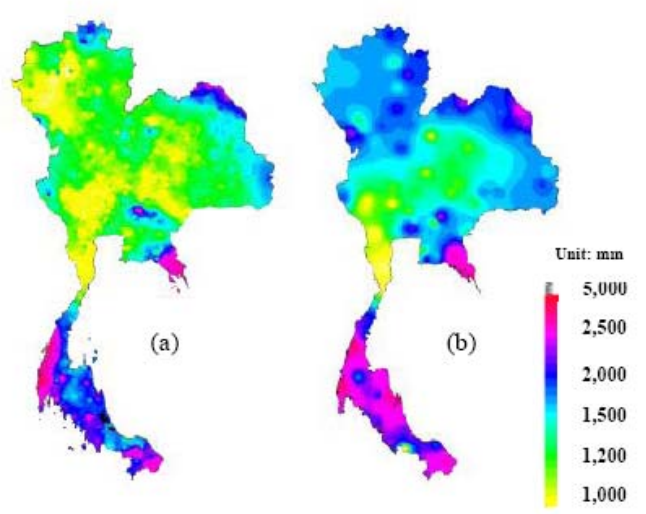

Fig. 3. Comparison of cumulative rainfall between (a) average annual rainfall (1950-1997) and (b) 2011. (HAII, Thailand).

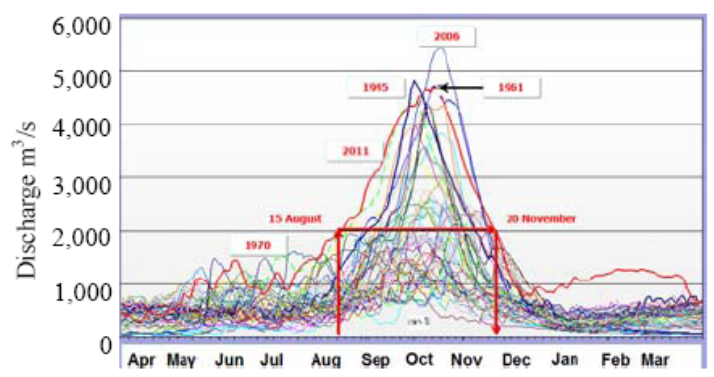

Fig. 4. The flood hydrograph at station C.2, Nakhon Sawan province. (RID, Thailand). 
Storm surge combined with high tides hit the Gulf of Thailand during the months of October and November 2011 also raised the sea water level and hindered the draining system (e.g. pumps and control structures) into the sea. The severe flood and extensive damage in the lower northern part has extended to the central part, most areas of northern, eastern and western Bangkok metropolitan area and its vicinity. During flood periods, a lot of protection dikes were broken and a mass of water flood was placed submerging the villages and industrial estates along the Chao Phraya River (Fig. 5). Most dikes failed due to water overtopping them and/or erosion between earthen dike and concrete control structure, but some failed when water passed underneath the levee foundations causing the levee wall to shift and consequently in catastrophic was suddenly breaching. Broken regulators and dikes resulted in flowing of water from the Chao Phraya River through irrigation canals and inundating large areas of paddy fields in Singburi, Ang Thong, Lopburi and Ayutthaya provinces. The strain was lessened on Bangkok as the lowland floodplain and paddy fields served as water retention areas.

By the beginning of October, most dams were almost over-capacity and being forced to release through emergency spillway, potentially worsening downstream flooding. Flooding in Ayutthaya city was worsened as flood water entering the downtown, inundating the Ayutthaya Historical Park and forcing evacuations. During this month (4-20 October 2011), all seven barriers poorly protected industrial estates dikes system because the height of dikes increased by using poor soil materials and/or sandbags, which were broken. Dozens of major factories, were completely flooded to the level about $1.5-3.0 \mathrm{~m}$ above the ground surface, resulted in country-wide disruption of manufacturing supply chains and virtually inaccessible. Airports of Thailand (AOT) declared the closure of Don Muang airport on 25 October as flood waters flowed on to the runways and affected the lighting system (Fig. 6). The $13 \mathrm{~km}$ flood wall built with the help from the Royal Thai Air Force, would prevent from water outside entering the site. All 7 industrial estates located in lowland swamp areas and ancient floodways for drained flood water from upstream to downstream areas at the Gulf of Thailand. Overall damage from the severe floods for industrial estates was worth THB 285 billion. As a result, it was expected that Thailand's overall economic growth in 2011 was focus to be lower than the initial estimated growth of $3.8 \%$.

The World Bank has been reported that the total damage and losses from the Thailand floods in 2011 amounted to THB 1.44 trillion, which was $56 \%$ of the total economic. The manufacturing sector bore roughly $70 \%$ of the total damage and losses due to the flooding of seven industrial estates in Ayuthaya and Pathum Thani provinces from October to November 2011. Overall, approximately 90 percent of the damage and losses from the floods were borne by the private sector.

Strengthen flood management through integrated water resources management (IWRM) is a key step towards water management for consumption, productive use and disaster risk management related to droughts, floods and tropical storms. The total concept is, upstream area - storing the water (management of water in reservoirs), midstream area retarding the water (management of water in rivers and floodplains - called monkey cheek) and in downstream area draining the water (management of water drain to the sea). Some key structural recommendations for flood management prioritize the immediate rehabilitation of hydraulic assets and an increase in drainage capacity. Undertaking a design review of critical flood embankments, and carrying out dam safety reviews immediately are integral to ensuring the safety of flood control structures going into the next rainy season. Non-structural is also recommended, such as, single command center, effective early warning system, evacuation, emergency response and afforestation.

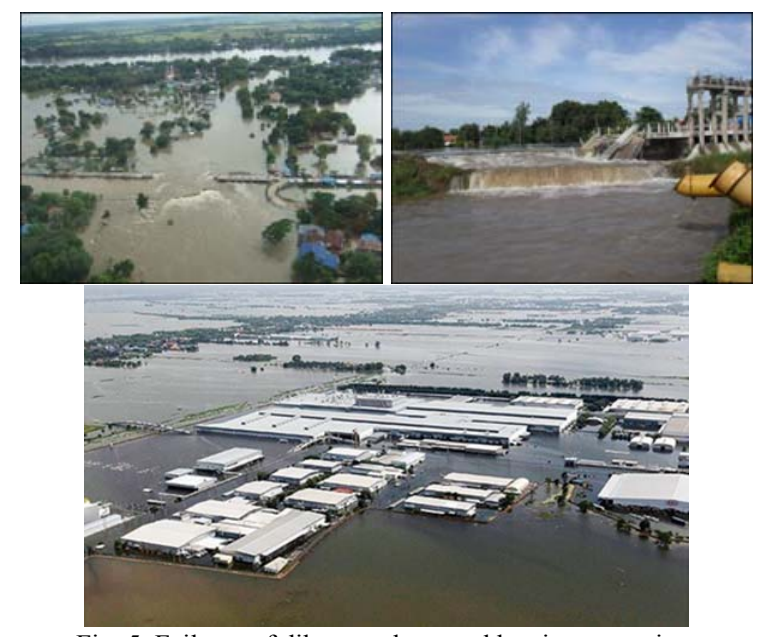

Fig. 5. Failures of dike, regulator and barrier protection.

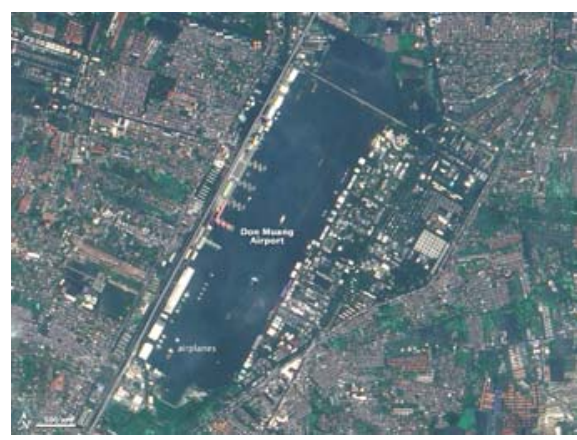

Fig. 6. Don Muang airport.

(http://earthobservatory.nasa.gov/IOTD/view.php?id=76282)

\section{IRIC MODEL}

The International River Interface Cooperative (iRIC) software application provides an integrated river simulation environment. iRIC provides a comprehensive, unified environment in which data necessary for river analysis solvers (hereafter: solvers) can be compiled, rivers can be simulated and analytical results can be visualized. The general operations for iRIC simulations, and the window for each process are shown in Fig. 7 The set of continuity and momentum equations of two-dimensional unsteady flow in the Cartesian co-ordinate system can be expressed as [4]-[8]

Continuity equation:

$$
\frac{\partial h}{\partial t}+\frac{\partial(h u)}{\partial x}+\frac{\partial(h v)}{\partial y}=0
$$

Momentum equations: 


$$
\begin{gathered}
\frac{\partial(h u)}{\partial t}+\frac{\partial\left(h u^{2}\right)}{\partial x}+\frac{\partial(h u v)}{\partial y}=-g h \frac{\partial H}{\partial x} \\
-\frac{\tau_{b x}}{\rho}+\frac{\partial}{\partial x}\left[v \frac{\partial(h u)}{\partial x}\right]+\frac{\partial}{\partial y}\left[v \frac{\partial(h u)}{\partial y}\right] \\
\frac{\partial(h v)}{\partial t}+\frac{\partial(h u v)}{\partial x}+\frac{\partial\left(h v^{2}\right)}{\partial y}=-g h \frac{\partial H}{\partial y} \\
-\frac{\tau_{b y}}{\rho}+\frac{\partial}{\partial x}\left[v \frac{\partial(h v)}{\partial x}\right]+\frac{\partial}{\partial y}\left[v \frac{\partial(h v)}{\partial y}\right]
\end{gathered}
$$

where $h=$ water depth; $u, v=$ depth averaged velocity components; $\tau_{b}=$ bed shear stress; $\rho=$ water density; $H=$ stage height $\left(H=h+z_{b}\right) ; z_{b}=$ bed elevation; $v=$ eddy viscosity; $t=$ time; and $x, y=$ spatial coordinate components in the Cartesian system. Bed shear stress components are written as follows

$$
\begin{gathered}
\tau_{b x}=\rho C_{f} u \sqrt{u^{2}+v^{2}} \\
\tau_{b y}=\rho C_{f} v \sqrt{u^{2}+v^{2}} \\
v=\frac{\kappa}{6} u \times h
\end{gathered}
$$

where $C_{f}=$ bed friction coefficient; $\kappa=$ Karman constant; and $u_{*}=$ shear velocity.

The Cartesian coordinate system employed in the above equations was transformed into the moving boundary-fitted coordinate system using the Jacobian chain rules.

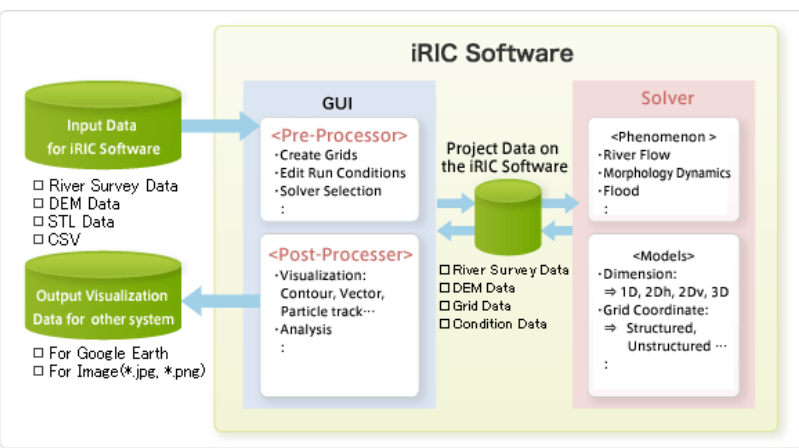

Fig. 7. General operations for iRIC simulations. (http://i-ric.org/en/introduction)

The high-order Godunov scheme known as Cubic Interpolation Psuedoparticle (CIP) method was used for application of the equations of water flow. This method interpolated physical values between grid points at the previous time step by using cubic equation under the assumption that spatial gradients of those physical values were also transported by similar convective equations. This method could calculate precise profiles of convectional variables by information of small number of adjacent cells. The computation procedure was used to calculate the changes in flow fields and the floodplain configuration with time at infinitesimal intervals up to the CFL conditions.

\section{Simulation Results AND Disscussion}

Performance of the iRIC model was applied to simulate the Lower Chao Phraya floodplain, which is from Nakhon Sawan Province (at station C.2) to river estuary at the Gulf of
Thailand. The simulation has focused on the applicability of water flow and flood propagation by using flow conditions in the year of 2011 .

\section{A. Model Calibration}

The comparison of time series of measured (GISTDA satellite map) and simulated flood depth and propagation direction (iRIC) are shown in Fig. 8. Good agreement in both for flood depth between simulated (right) and measured (left), and for propagation direction was achieved. It was observed that flood water was flow across from Chao Phraya river basin to Thachin river basin (from east to west direction) at Ang Thong and Ayutthaya provinces.

Secondly, the comparison of flood depth between simulated results and measured data (IMPAC-T), good agreement was achieved in Fig. 9. However, the comparison was maximum depth during and after flood events. Flooded areas were not so clear for measured data. It is noted that the maximum flood depth was over $5.1 \mathrm{~m}$ above the ground surface in some areas along the Chao Phraya River.

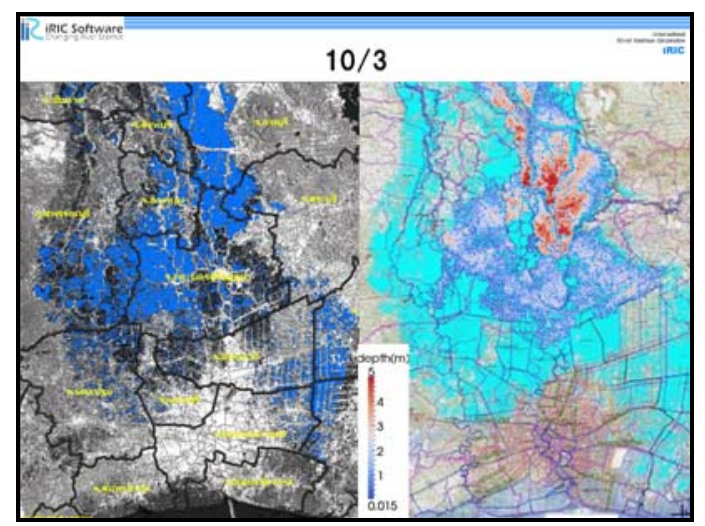

(a)

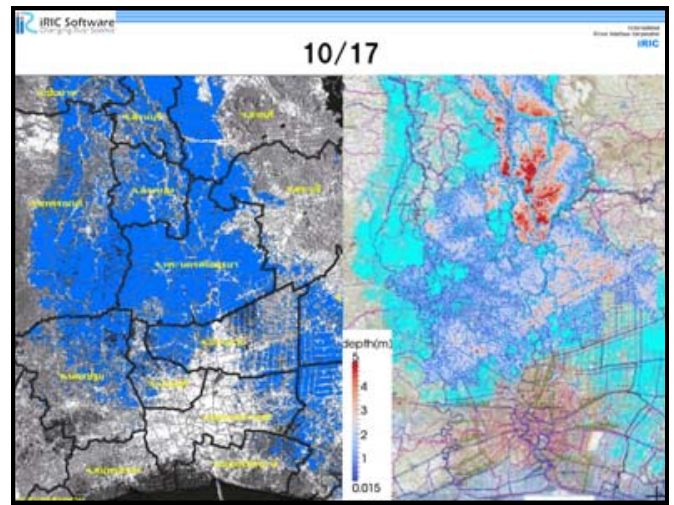

(b)

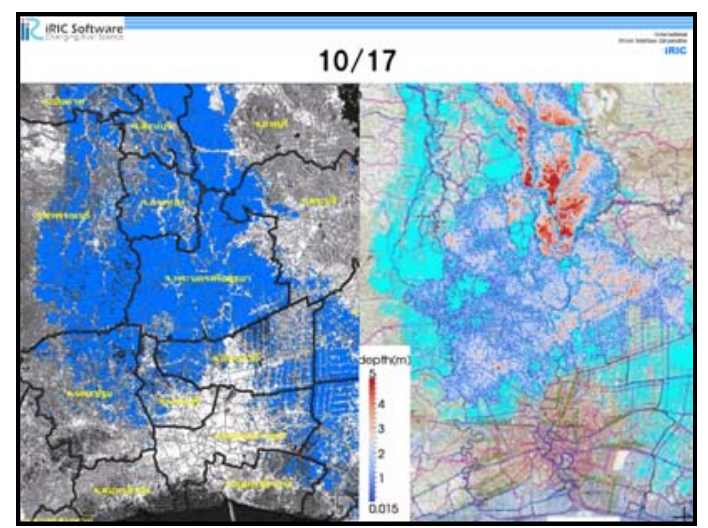

(c) 


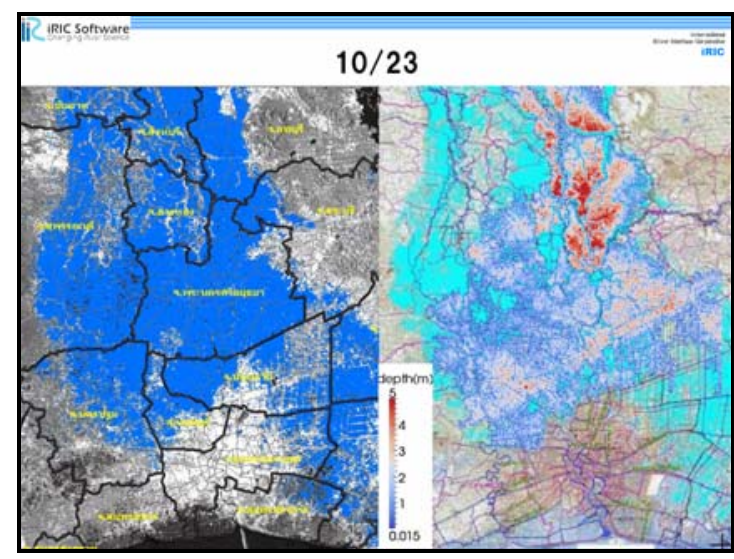

(d)

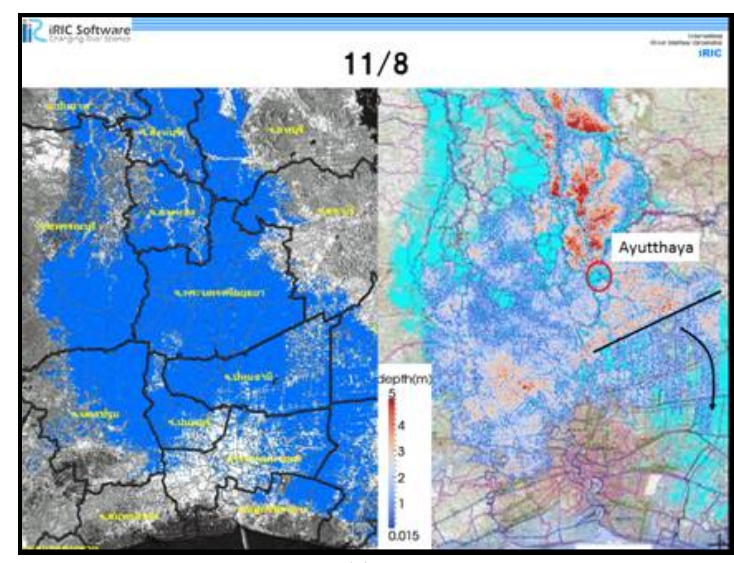

(e)

Fig. 8. Comparison of time series of flood depth and propagation between simulated results (right) and GISTDA satellite data (left). (a) $\mathrm{T}=3$ October 2011, (b) $\mathrm{T}=9$ October 2011, (c) $\mathrm{T}=17$ October 201, (d) $\mathrm{T}=23$ October 20111 and (e) $\mathrm{T}=11$ November 2011.

Good performance of simulated results was observed in both flood depth and propagation direction, therefore, indicating that iRIC model simulation is exploitable to simulate Thailand flood in 2011.

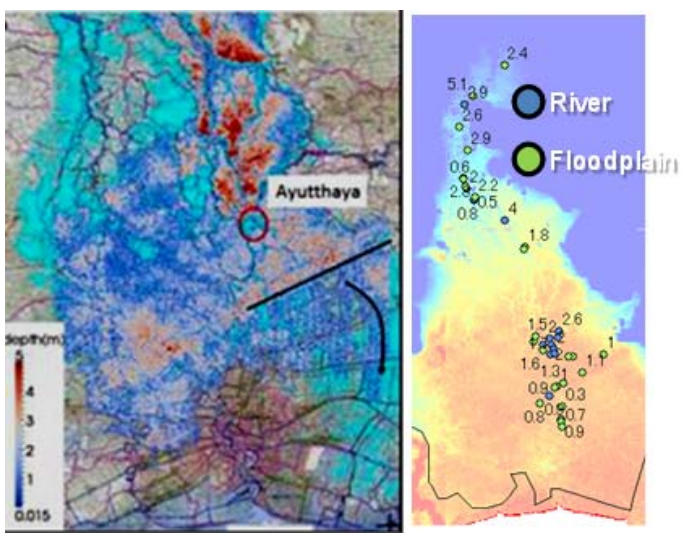

Fig. 9. Comparison of flood depth between simulated results (right) and measured data (IMPAC-T)

\section{B. Model Simulation}

For the model simulation and application, the two scenarios from industrial park were simulated, which the present scenarios (before flood) and bank protection scenarios (after flood). The comparisons of time series of flood depth are shown in Fig. 10. The flooded areas were seen to move slowly southward to Bangkok Metropolitan areas, and then, had been passed through all 7 industrial park areas. The result, therefore, indicated that all 7 industrial estates located in lowland swamp areas and ancient floodways were predicted to be high flood risk areas. However, a more detailed investigation is necessary.

It was found that after bank protection construction, only a few effects on flood depth about $5.0-10.0 \mathrm{~cm}$ occurred in the first week, and then, but no difference of flood depth in two scenarios. This fact may be explained by several reasons: 1) flood duration is very long and 2) flood areas and volume is very huge compare with protection areas.

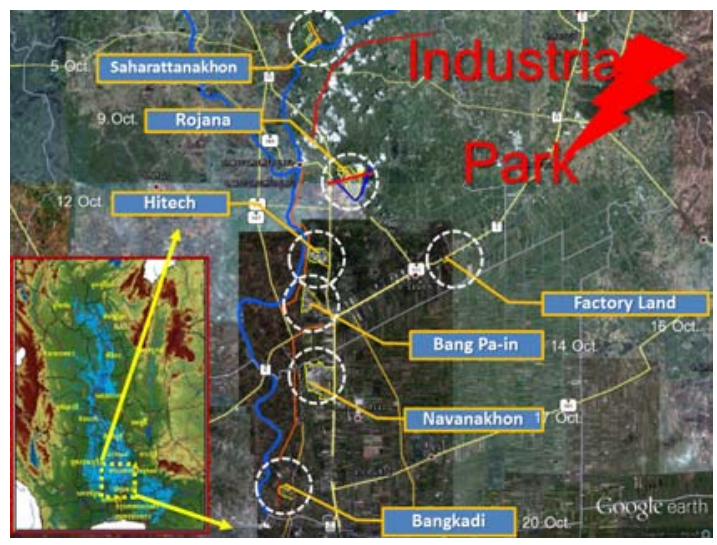

(a)

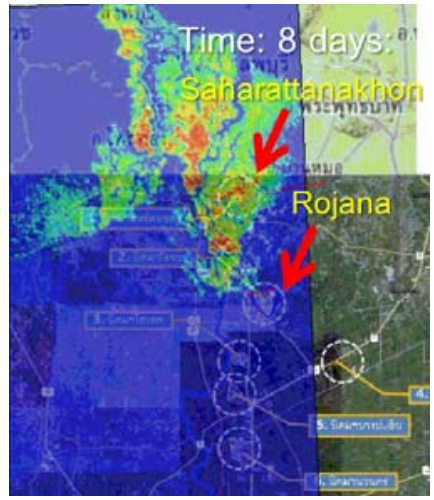

(b)

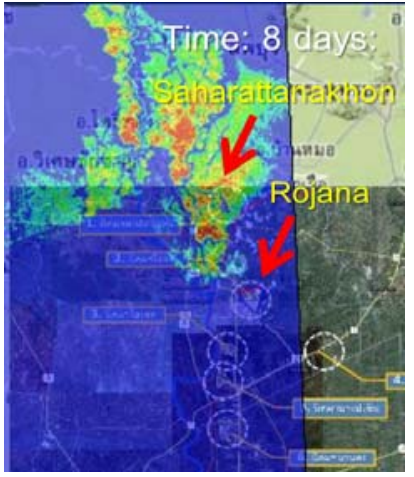

(c)

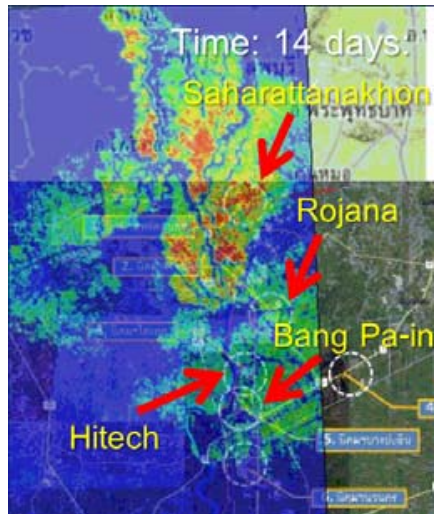

(d) 


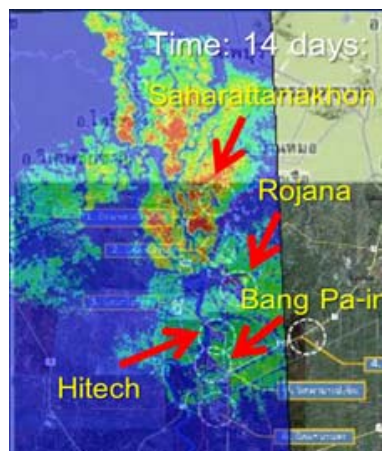

(e)

Fig. 10. Comparison of flood depth between present scenarios (before flood) and with bank protection scenarios (after flood). (a) lacation of Industrial estate, (b) $\mathrm{T}=8$ days, (present scenarios), (c) $\mathrm{T}=8$ days, (present scenarios), (d) $\mathrm{T}=14$ days, (present scenarios) and (e) $\mathrm{T}=14$ days, (present scenarios).

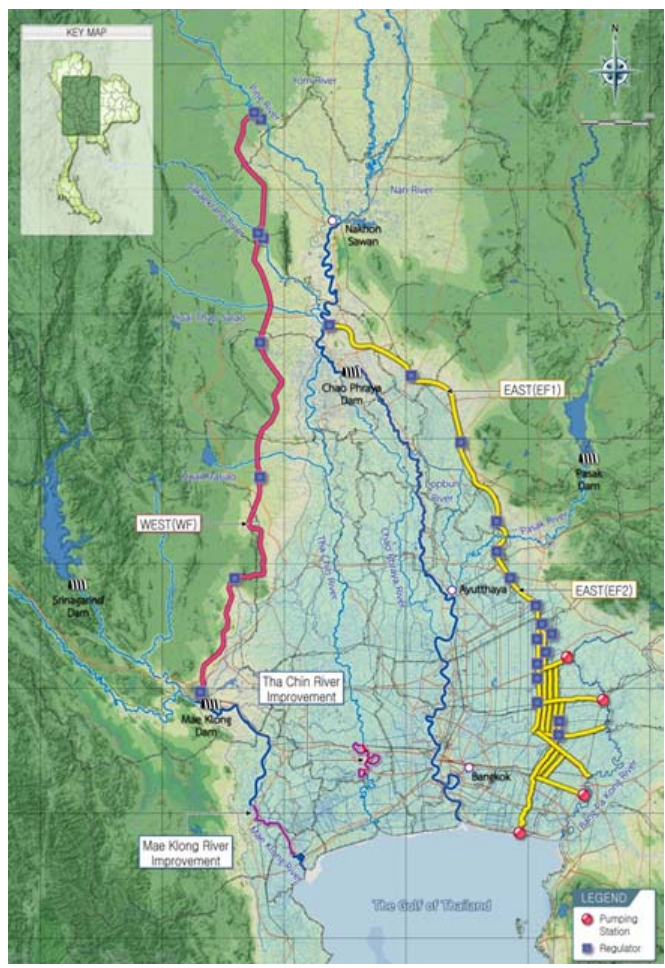

Fig. 11. Flood diversion channel proposed by the government.

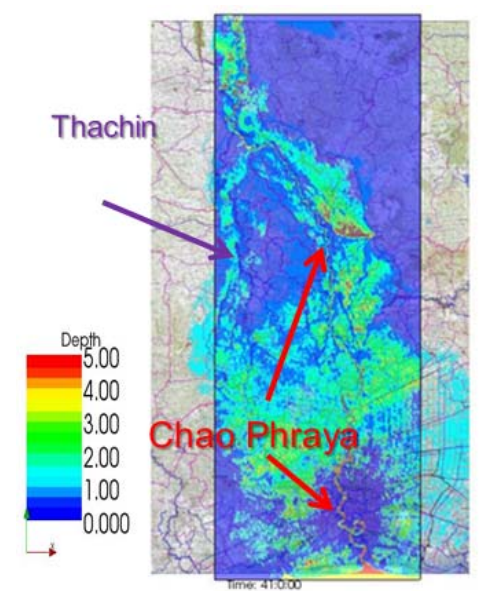

Fig. 12. Simulated flood depth in the year of 2011 (present scenario).

Under the BTH 350 billion water and flood management scheme, the Thai Government proposed a possible solution to reduce the frequency of flood risks by constructing a flood diversion channel in Chao Phraya River to the Gulf of Thailand. They consist of the flood diversion channel on the east and west bank with total flood discharges of 300 and $1,200 \mathrm{~m}^{3} / \mathrm{s}$, respectively. The purpose of this flood diversion channel is to reduce the water level of the river during high water from flooding in downstream areas (Fig. 11).

In this study, the flood diversion channel on the east bank of the Chao Phraya River (Chainat-Pasak) is proposed, with total flood discharge of $500 \mathrm{~m}^{3} / \mathrm{s}$. The comparisons of flood depth are shown in Fig. 12 and Fig. 13. It was found that the flooded areas were seen to dramatically decrease in both Thachin and Chao Phraya River (flooded areas in circles).

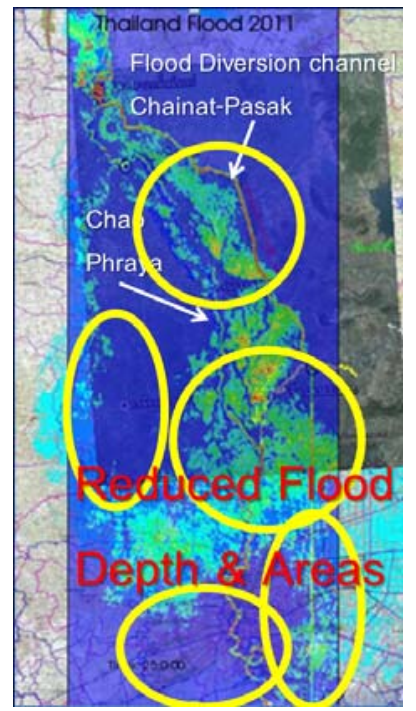

Fig. 13. Simulated flood depth after construction of new diversion channel with flood discharge of $500 \mathrm{~m}^{3} / \mathrm{s}$ on the East bank.

\section{CONCLUSION}

The worst flooding in seventy-two years during the 2011 was affected by five key tropical storms and monsoons passing through. These flood left severe impairments to the country's infrastructure, economy, industrial sector, and society. Overall, around 90 percent of the damage and losses were borne by the private sector.

Some numerical results compared with field and satellite data are presented to demonstrate applicability of the iRIC model. Good performances of simulated results were observed in both flow fields and flood propagations, indicating that the iRIC model is reasonably exploitable. For the model simulation, it was found that after industrial estates bank protection construction, only a few effects on flood depth was observed. The proposed flood diversion channel of $500 \mathrm{~m}^{3} / \mathrm{s}$ can be dramatically decreased flood depth in both Thachin and Chao Phraya River.

\section{ACKNOWLEDGMENT}

The author would like to thank Dr. Toshiki Iwasaki, Hokkaido University for provision of some calculation results.

\section{REFERENCES}

[1] Bank of Thailand, Thailand Floods 2011: Impact and Recovery from Business Survey, 2011.

[2] The Ministry of Finance, Royal Thai Government and The World Bank, Thailand Flooding 2554: Rapid Assessment for Resilient Recovery and Reconstruction Planning, 2011. 
[3] S. Wongsa, "Thailand Flood 2011," Journal of Disaster Research, vol. 8, no. 3, pp. 380-385, 2013.

[4] Y. Shimizu, "Mutual relation between riverbed and bank variation characteristics in river channel landform formation," Annual Journal of Hydraulic Engineering, vol. 47. pp. 643-648, 2003.

[5] C. Jang and Y. Shimizu, "Numerical simulation of relatively wide, shallow channels with erodible banks," Journal of Hydraulic Engineering, ASCE, vol. 131, no. 7, pp. 565-575, 2005.

[6] S. Wongsa and Y. Shimizu, "Numerical simulation of bed deformation in meandering and braiding channel," presented at Vietnam - Japan Coastal Workshop, Hanoi, Vietnam, 2006.

[7] S. Wongsa and Y. Shimizu, "The simulation of the Thailand central region flood in 2011: iRIC model," in Proc. 2nd EIT International Conference on Water Resources Engineering, Chiang Rai, Thailand, 2013.

[8] K. Tannok and S. Wongsa, "The application of iRIC program for simulation of flood area to effect from flood disaster in 2011: impacts from construction of the retaining wall at the industrial estates in Ayutthaya and Pathum Thani," presented at 19th NCCE, Khon Kaen, Thailand, 2014.

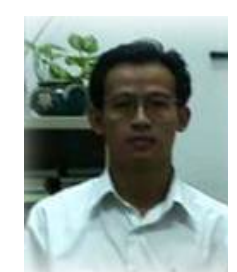

S. Wongsa was born in Thailand, on 7 January, 1969 $\mathrm{He}$ received his B. Eng in civil engineering from Kyushu Institute of Technology in Kitakyushu, Japan in 1993.

He received his M.Eng in hydraulics engineering from Kyushu Institute of Technology in Japan, 1995 and he received his Ph.D. in environment and resource engineering from Hokkaido University, in Hokkaido, Japan in 2004.

His major field of study includes numerical modeling, river engineering, morph dynamics and he are currently working a Wongsa, Advisory in sub-committee of Water Resources, EIT, Thailand. 